\title{
Effects of Natural Food Additives on The Protein Content of Adult and Immature Stages of The Wax Moth Endoparasitoid, Apanteles galleriae
}

\author{
Lamya M. Z. Abo Abdalla ${ }^{1}$ and Gadelhak G. Gadelhak ${ }^{2}$ \\ ${ }^{1}$ Department of Biological Control, Plant Protection Research Institute (Sabahia), Alexandria, EGYPT. \\ ${ }^{2}$ Department of Applied Entomology, Faculty of Agriculture, University of Alexandria, EGYPT
}

Received on: 16/12/2015

Accepted: 4/2/2016

\begin{abstract}
The endoparasitoid, Apanteles galleriae, is one of the effective parasitoids on the greater and lesser wax moths, Galleria mellonella and Achroia greissella. The parasitoid was kept in the laboratory on lesser wax moths, Achroia greissella as a host. Males and females were fed on pure honey, diluted honey (80\%), diluted honey + royal jelly $(20$ $\mathrm{mg} / \mathrm{ml})$, diluted honey + Pollen $(20 \mathrm{mg} / \mathrm{ml})$ and diluted honey + royal jelly + pollen (same ratio). Food substitutes were offered to the parasitoid freely. The resulting generation was then used for the protein content studies. The protein contents of both males and females were monitored throughout their life span. In addition, the protein contents of parasitoid larvae and pupae were monitored as well. Protein electrophoresis for previous treatments has shown heterogeneous band distribution when compared with controls. Band distributions and densities were characteristically variable over time, food supplement and insect stages.
\end{abstract}

Key words: Achroia greissella, Apanteles galleriae, protein content.

\section{INTRODUCTION}

The braconid, Apanteles galleriae Wilk., is one of the major parasitoids of wax moths. It was studied and was identified to the species level by several authors (Ibrahim, 1980; El-Hemeasy, 1983; Ibrahim et al., 1984; Al-Arnaooty, 1985 and Tawfik et al., 1985). The parasitoid, A. galleriae is a koinobiont, solitary and early instar larval endoparasitoid of many lepidopterous wax moths like Galleria mellonella, Achroia grisella, Achroia innotata Walker and Vitula edmandsae Packard (Shimamori, 1987; Watanabe, 1987 and Whitfield et al., 2001). Economic losses due to the infestation of wax moths could be of great concern since the damage caused could exceed several million dollars annually (Williams, 1976). In Apis cerana bee hives in China, Zhou et al. (1989) reported serious damages caused by G. mellonella reducing honey yields by more than $20 \%$. Parasitoids of wax moths are among the foremost candidates in the reconstruction of ecological balance and biological control applications since they pose lower environmental risks, tend to be host specific and are considered as ecological life vests in this regard (Hokkanen and Lynch, 1995; Andow et al., 1997 and Uçkan and Gülel, 2002). Earlier trials have been done through the use of egg parasitoids like Trichogramma evanescens, Trichogramma cacoeciae and Trichogramma minutum against species of wax moths (Boldt and Marston, 1974). Larval parasitoids have been known to be successful in the search for proper biological control agent.
One of them is Venturia (Nemeritis) canescens (Grav.), an ichneumonid, which was found by Salt (1976) to parasitize the larval stage in the laboratory. While Al-Arnaooty (1985) reported its presence in wax moth infested hives in the area of Qualiobia governorate in 1983. Females of the ectoparasitoid, Bracon hebetor (Say), were found to oviposit on final instars of wax moth larvae (Awadallah et al., 1985; Tawfik et al., 1985 and Tharwat, 1991). The endoparasitoid, Apanteles galleriae, is one of the major parasitoids of wax moths. Both the greater and the lesser wax moth second and third instar larvae are liable to be parasitized by the Apanteles galleriae females.

Suitable food substituents and supplements have been reported to be important factors behind the success of any biological control program (Wolcott, 1942; Hocking, 1966). To raise the impact of parasitoids on their host populations, additional food source strategies could be implemented. To date, only circumstantial evidence is available to indicate that natural enemies benefit from the availability of food supplements and that supplemental feeding could actually be translated into better host regulation (Wäckers, 2002). In nature, adult parasitoids require sugar solutions, such as nectar or honeydew, as their main source of energy (Jervis and Kidd, 1986). Such feeding can increase parasitoid longevity (Wäckers, 1998, 2001; Siekmann et al., 2001) as well as fecundity (Olson and Andow, 1998; Schmale et al., 2001). Well-fed parasitoids are usually more active and focused in seeking out their hosts (Wäckers, 1994; Takasu and 
Lewis, 1995). This concept of facultative phytophagy by entomophagous insects, may allow them to survive periods of low prey densities (Benton and Crump, 1981; Hemptinne and Desprets, 1986; Hagen, 1986; Hodek and Honek, 1996; Wiedenmann et al., 1996), or provide them with critical or extra nutrients necessary for egg production or overwintering (Hagen, 1962; Schneider, 1969; Jervis and Kidd, 1986; Hodek and Honek, 1996). The general idea is that many arthropod predators and parasitoids exhibit stagespecific external feeding where they include plantderived foods, such as pollen, nectar, extra-floral nectar or honeydew, in their immature and/or adult diet (Hagen, 1986 ).

It is well documented that insect natural enemies feed on pollen, but the nutritional suitability of pollen for these natural enemies is not well understood (Nordlund et al., 2001; Lundgren and Wiedenmann, 2004). Studies have generally reported protein to be $23-27 \%$ of the dry weight of pollen grains (Goss, 1968; Roulston et al., 2000). This was investigated by Lundgren and Wiedenmann (2004), who found that aphids + pollen grains were superior to corn pollen for the development of the predator, Coleomegilla maculate since there were significant increases in fecundity and weight as well as a significant decrease in larval durations. Another food supplement that could be used in feeding entomophagous insects is the honeybee royal jelly which is considered as a main source for proteins among other nutrients. Royal jelly contains various components: $60-70 \%$ water, $12-15 \%$ protein, and $10-16 \%$ total sugar, lipids, vitamin, salts and free amino acids (Chen \& Chen, 1995; Howe, Dimick, \& Benton, 1985; Simuth, 2001). Most of its soluble proteins are called major royal jelly proteins (MRJPs) (Schmitzova et al., 1998; Simuth, 2001). MRJPs are thought to be the major factor responsible for the specific physiological role in queen honeybee development, as MRJPs include numerous essential amino acids, similar to known protein families like albumin and casein (Schmitzova et al., 1998). MRJPs were found to be composed of five monomers that are bound by non-covalent bonds (Tamura et al, 2009). In the mean time, Abo Abdalla (2006) found that the supplemental feeding of the endoparasitoid, $A$. galleriae with pollen and royal jelly, have increased the female fecundity and decreased larval durations as well.

This project is aimed at addressing the question of how food supplements, namely pollen and royal jelly, may affect the parasitoid, A. galleriae protein content and protein profile.

\section{MATERIALS AND METHODS \\ Insects}

The lesser wax moth Achroia grisella (F.) was reared as the host insect. A laboratory culture of the insect was established after being collected from local infested apiaries. The culture was maintained for an entire year where the biology was monitored under laboratory conditions $\left(21-28{ }^{\circ} \mathrm{C}\right.$ and $60-$ $85 \% \mathrm{RH})$. A. grisella larvae were reared on a semiartificial diet that was developed by El-Kifl (1980) and modified by Abo Abdalla (2006).

A colony of the parasitoid, Apanteles galleriae Wilk. was kept in the laboratory on A. grisella larval stage. To maintain a good parasitoid laboratory population, parasitism was conducted on the third larval instars three times a week. Adults were kept on pure honey as a food source.

\section{Food supplements}

Four food supplements were used in these experiments, 80\%-diluted honey (HW). Diluted honey + royal jelly $(20 \mathrm{mg} / \mathrm{ml})$ (HWRJ), diluted honey + Pollen $(20 \mathrm{mg} / \mathrm{ml})$ (HWP) and diluted honey + royal jelly + pollen (HWPRJ) (Abo Abdalla, 2006). The honey used was an alfalfa harvest and the pollen grains were bee-collected mostly from Faba bean flowers

\section{Protein determination}

An entire generation of $A$. galleriae was fed on the above food supplements before protein studies are commenced. Male and female adults were collected after $0,2,4,6,8,10,12,14,16,18$ and 20 days of feeding. For the larval stage, first, second, early third and late third instar larvae in addition to the pupal stage were also collected. Protein content was estimated using the method of (Lowery et al., 1951). Protein concentrations were measured using a double beam, Nicolete Evolution 100 UV-Visible spectrophotometer (Thermo Electron Corporation, UK)

\section{Electrophoresis}

Based on the data of the protein determination, adult males and females were chosen at 2 and 16 old-days of feeding in addition to late third larval instar and the pupal stage for the study of the protein electrophoresis. SDS-PAGE electrophoresis was conducted using the reported discontinuous buffer method by Laemmli (1970).

\section{Sample preparation}

Samples were mixed with a sample buffer $(2 \%$ SDS, $10 \%$ glycerol, $0.002 \%$ bromophenol blue and 5\% 2-mercaptoethanol). Afterwards, samples were submitted to heat treatment for $5 \mathrm{~min}$. and were allowed to cool to room temperature prior to application.

\section{Gel preparation}

A $12.5 \%$ resolving gel was prepared by mixing of acrylamid bis-acrylamid $(10 \mathrm{~mL})$, resolving buffer stock (3.0 M Tris-HCl, pH 8.8) (3.75 mL), SDS $10 \%(0.3 \mathrm{~mL})$, freshly prepared Ammonium 
persulfate $1.5 \%(1.5 \mathrm{~mL})$, D-water $(14.5 \mathrm{~mL})$ and TEMED (N,N,N,N-tetramethylene diamide) (0.015 $\mathrm{mL}$ ). The stacking gel was prepared similarly by the addition of acrylamid bis-acrylamid $(2.5 \mathrm{~mL})$, stacking gel buffer stock ( $0.5 \mathrm{M}$ Tris $\mathrm{HCl}, \mathrm{pH} 6.8)$ $(5.0 \mathrm{~mL})$, SDS $10 \%(0.2 \mathrm{~mL})$, freshly prepared Ammonium persulfate $1.5 \%(1.0 \mathrm{~mL})$, D-water $(11.0 \mathrm{~mL})$ and TEMED $(0.015 \mathrm{~mL})$. After polymerization, samples were loaded as $7.5 \mathrm{ul}$ per well of each prepared sample. Electrophoresis was performed using Mini-Protean II (Bio-Rad, Richmond, CA) at $75 \mathrm{v}$ through the stacking gel followed by $125 \mathrm{v}$ through the resolving gel $(2 \mathrm{~h})$. Reservoir buffer $(0.25 \mathrm{M}$ Tris, $1.9 \mathrm{M}$ glycerol, $1 \%$ SDS at $\mathrm{pH} 8.3$ ), was used during the electrophoresis run. The gel was then stained with Comassie Blue $\mathrm{R}-250$ for $2 \mathrm{~h}$, then the excess stain was removed from the gel by a de-staining solution $(\mathrm{AcOH}$, $\left.\mathrm{MeOH}, \mathrm{H}_{2} \mathrm{O}, 1: 3: 6\right)$.

Standared protein markers (Sigma, St. Louis, MO, USA)were myosin (200 kDa), B-Galactosidase (116 kDa), Phosphorylase b (97 kDa), Albumin (66 $\mathrm{kDa})$, Glutamic Dehydrogenase (55 kDa), Ovalbumin(45 kDa), Glyceraldehyde-3-phosphate Dehydrogenase (36 kDa), Carbonic Anhydrase (29 $\mathrm{kDa}$ ), Trypsinogen (24 kDa), Trypsin Inhibitor (20 kDs), a-Lactalbumin (14 kDa) and Aprotinin (6.5 $\mathrm{kDa})$. Quantitative determination of the resolved protein bands were carried out using the TOTALLAB software v-2003 (Appligene).

\section{Statistical Analysis}

Experiments were replicated and statistical analysis was computed. Statistical analysis was done according to Gomez and Gomez (1984). Comparisons among means were carried out using the LSD at 0.01 probabilities.

\section{RESULTS AND DISCUSSION}

The endoparasitoid, Apanteles galleriae Wilk., was kept in the laboratory and was offered a supplemental feeding on $80 \%$-diluted honey (HW), diluted honey + royal jelly $(20 \mathrm{mg} / \mathrm{ml})$ (HWRJ), diluted honey + Pollen (20 mg/ml) (HWP) and diluted honey + royal jelly + pollen (HWPRJ). The effects of such feeding on the parasitoid, $A$. galleriae protein content and protein profile are discussed.

\section{Protein Content}

The endoparasitoid, A. galleriae, males, females, larval instars and pupal stage that were allowed the four food supplements, were sampled over time and protein contents were determined. Male total proteins (Fig. 1) indicated that all treatments including the control started to increase from the $6^{\text {th }}$ day while the pollen treatment (HWP) started earlier on the $4^{\text {th }}$ day. The highest protein values were recorded on the $14^{\text {th }}, 14^{\text {th }}, 20^{\text {th }}, 12^{\text {th }}, 18^{\text {th }}$ days for the control (honey), HW, HWP, HWRJ and HWPRJ, respectively. Female total proteins (Fig. 2) showed that all treatments started to increase from the $2^{\text {nd }}$ day except for the water diluted honey and pollen which started from the $4^{\text {th }}$ day. The highest value for the control, diluted honey, pollen, royal jelly and pollen \& royal jelly were $12^{\text {th }}, 16^{\text {th }}, 14^{\text {th }}$, $20^{\text {th }}$, and $10^{\text {th }}$ days, respectively. For the larval stage (Fig. 3) no difference in the protein content was recorded between all treatments in the early first, late first, second and early third instars. Differences were prominent at the late third instar where the pollen treatment exhibited the highest protein content followed by the royal jelly, the control, the water diluted honey and the least was in the case of pollen and royal jelly treatments. While, in the pupal stage (Fig. 4) protein content was at its highest value in the combined treatment and the least was for the royal jelly. Statistical analysis have shown that there was a high significant differences in the protein values between sex, time, stages and food supplements at $\mathrm{p}=0.01$ (Tables $1 \& 2$ ).

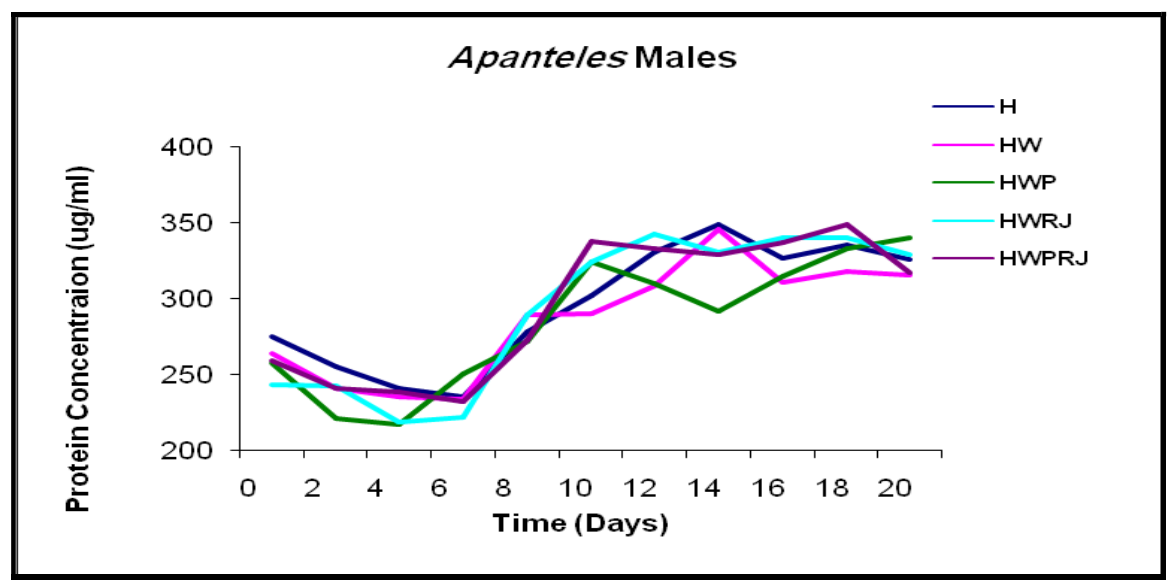

Figure 1: Protein concentration of adult males, $A$. galleriae fed on control honey $(\mathrm{H})$, diluted honey (HW), pollen (HWP), royal jelly (HWRJ) and both pollen and royal jelly (HWPRJ) for a period of 20 days. 


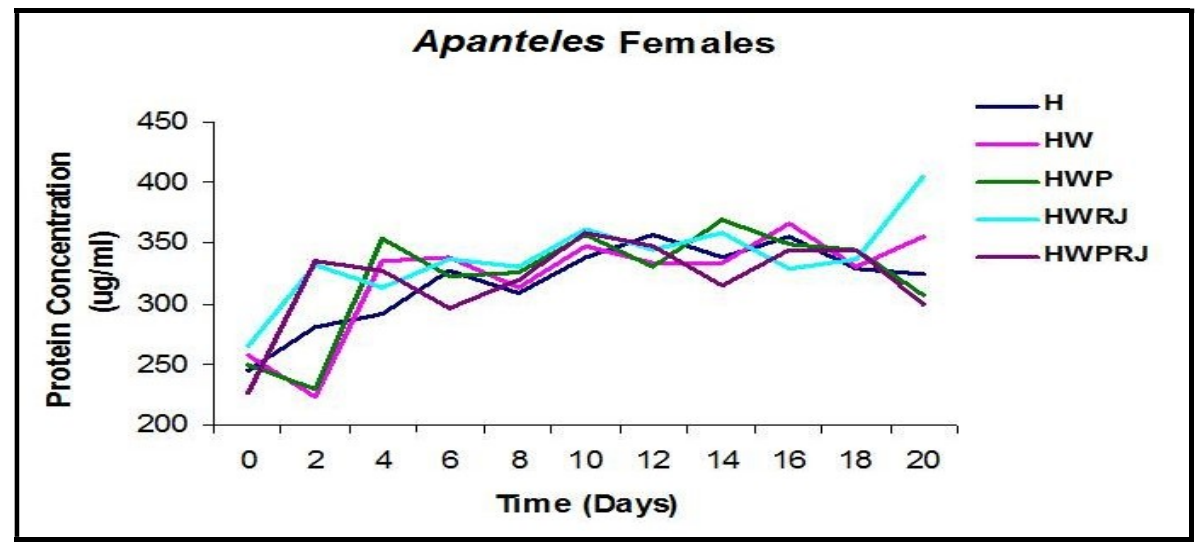

Figure 2: Protein concentration of adult females, A. galleriae fed on control honey (H), diluted honey (HW), pollen (HWP), royal jelly (HWRJ) and both pollen and royal jelly (HWPRJ) for a period of 20 days.

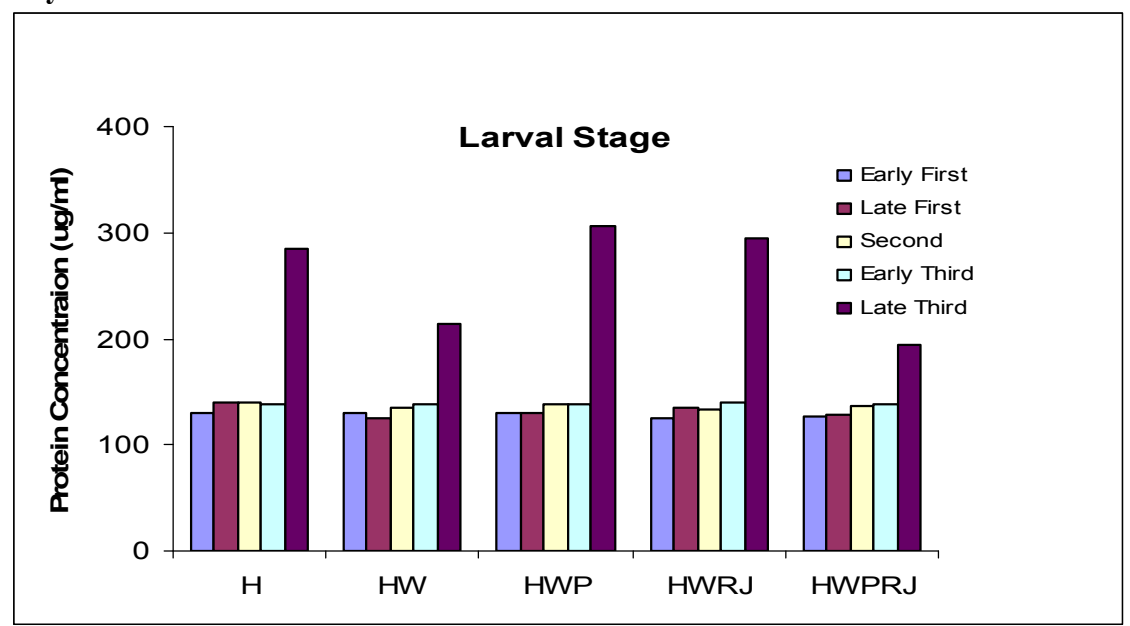

Figure 3: Protein concentration of the larval stage of A. galleriae fed (as adults) on control honey (H), diluted honey (HW), pollen (HWP), royal jelly (HWRJ) and both pollen and royal jelly (HWPRJ). Protein determinations were carried out on the early first, late first, second, early third and late third instars.

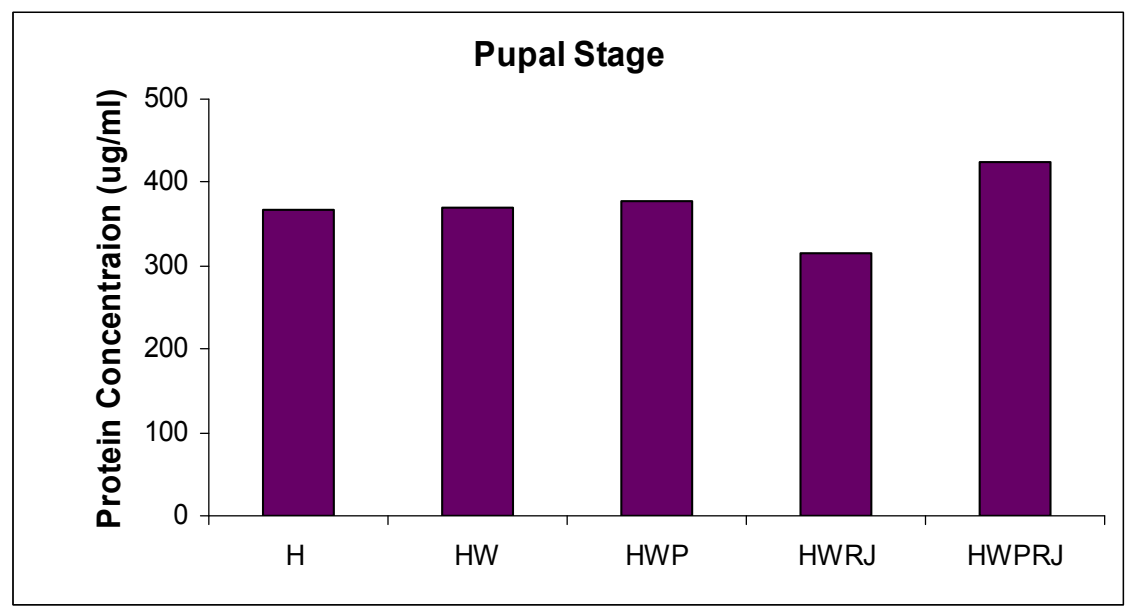

Figure 4: Protein concentration of the pupal stage of A. galleriae fed (as adults) on control honey (H), diluted honey (HW), pollen (HWP), royal jelly (HWRJ) and both pollen and royal jelly (HWPRJ). 
Table 1: Differences in protein contents between the major stages of the endoparasitoid, $A$. galleriae.

\begin{tabular}{lcccccccc}
\hline Stage & Male & Female & $\begin{array}{c}\text { Early 1 } \\
\text { instar } \\
\text { larvae }\end{array}$ & $\begin{array}{c}\text { Late 1 } \\
\text { instar } \\
\text { larvae }\end{array}$ & $\begin{array}{c}\mathbf{2}^{\text {nd }} \text { instar } \\
\text { larvae }\end{array}$ & $\begin{array}{c}\text { Early 3 } \\
\text { instar } \\
\text { larvae }\end{array}$ & $\begin{array}{c}\text { Late 3 }^{\text {rd }} \\
\text { instar } \\
\text { larvae }\end{array}$ & $\begin{array}{c}\text { Pupal } \\
\text { Stage }\end{array}$ \\
\hline $\begin{array}{l}\text { Protein } \\
\text { Content } \\
(\mathrm{ug} / \mathrm{ml})\end{array}$ & $278.6^{\mathrm{c}}$ & $310.8^{\mathrm{b}}$ & $132.6^{\mathrm{f}}$ & $128.5^{\mathrm{f}}$ & $139.6^{\mathrm{ef}}$ & $138.9^{\mathrm{e}}$ & $284.1^{\mathrm{d}}$ & $365.9^{\mathrm{a}}$ \\
\hline
\end{tabular}

Table 2: Differences in protein contents between the food supplements given to adults of the endoparasitoid, A. galleriae.

\begin{tabular}{lcccccc}
\hline & H & HW & HWP & HWRJ & HWPRJ & LSD \\
\cline { 2 - 7 } & \multicolumn{7}{c}{ Protein content (ug/ml) } \\
\hline Males & 278.6 & 279.6 & 283.2 & 285.3 & 286.7 & 14.8 \\
\hline Females & $310.8^{\mathrm{b}}$ & $312.5^{\mathrm{b}}$ & $323.1^{\mathrm{ab}}$ & $330.4^{\mathrm{a}}$ & $327.9^{\mathrm{a}}$ & 11.5 \\
\hline
\end{tabular}

Protein accumulation have started in the early third instar larvae and continued where it reached it's highest at the pupal stage $(365.9 \mathrm{ug} / \mathrm{ml})$. Females significantly contained higher protein concentrations than males being 310.8 and $278.6 \mathrm{ug} / \mathrm{ml}$, respectively. Protein contents differed between treatments and sex as shown in Table(2). The highest protein value corresponded to the pollen treatment where it reached $228.4 \mathrm{ug} / \mathrm{ml}$ while the lowest was for the water diluted honey being 215.1 $\mathrm{ug} / \mathrm{ml}$ for males. Wäckers(2002) argued in favor of using the additional food source strategies to raise the impact of parasitoids on their host populations. In addition, it does provide them with critical or extra nutrients necessary for higher egg production (Jervis and Kidd, 1986; Hodek and Honek,1996). Supplemental feeding on floral and extra-floral nectar and pollen is essential for them and are considered as excellent sources of carbohydrates and proteins for many entomophagous insects (Jervis \& Kidd, 1996; Van Driesche \& Bellows, 1996). Studies have shown that access to these floral resources increases survival and reproduction of these insects (Wäckers, van Rijn, \& Bruin, 2005; Wade \& Wratten, 2007; Kehrli \& Bacher, 2008).

\section{Protein bands of controls}

The analysis of the protein profile for stages of A. galleriae was done using SDS-PAGE protein electrophoresis. Band patterns were checked and compared between controls and treatments. When controls (Honey fed only) were compared for males ( 2 and16 days, Fig. 5), females (2 and16 days, Fig. 6), larvae (Fig. 7) and pupae (Fig. 8), various band pattern differences appeared. Stage-specific distinctive bands distribution were noticed. Four of these bands appeared only in males age two-days at $50.5,67.5,84.9$ and $119.8 \mathrm{kDa}$ and their percentages were $(5.5 \%), \quad(8.6 \%), \quad(3.9 \%)$ and $(5.5 \%)$, respectively. After 16 days, males protein profile showed five characteristic bands at $36.5(7.8 \%)$, 43.1 (8.9\%), 69.7 (9.1\%), $100.7(5.1 \%)$ and 140.4 $\mathrm{kDa}(6.5 \%)$ (Fig. 5 and Table 3). Female band distribution (after 2 days) showed only 2 femalespecific bands at $66.0(5.2 \%)$ and $182.1 \mathrm{kDa}(3.9 \%)$ that did not appear in other stages. After 16 days, four of these bands have appeared at $10.53(6.6 \%)$, $58.2(4.5 \%), 80.2(4.8 \%)$ and $136.7 \mathrm{kDa}(4.4 \%)$. At the larval stage, four characteristic bands appeared at $32.8(6.6 \%), 60.4(7.6 \%), 83.4(6.7 \%)$ and 172.6 $\mathrm{kDa}(5.8 \%)$. The pupal stage did not show any characteristic bands at any molecular weight. The above data would be useful when identifying bands that correspond to each stage of A. galleriae (Fig. 6 and Table 3).

\section{Protein bands of treatments}

The effect of the four treatments (food supplements) compared to the control were analyzed for both males and females of A. galleriae. For the two-days old males and against the 14 bands appeared in the control, only 12, 13, 10 and 12 bands appeared in the water diluted honey, pollen, royal jelly and the combined treatment, respectively. Out of these bands, four have appeared only in the control at $21.0(9.3 \%), 67.5(8.6 \%), 84.9(3.9 \%)$ and $119.8 \mathrm{kDa}(5.5 \%)$ of the 2 days old males. In the same manner, the band at $28.0 \mathrm{kDa}(5.7 \%)$ appeared only in the pollen \& royal jelly treatment as well as the bands at 57.5(8.4\%), 86.2(6.8\%), and $172.7 \mathrm{kDa}$ $(9.0 \%)$ also. The royal jelly treatment showed only one band at $75.7 \mathrm{kDa}(10.1 \%)$ that was not corresponded in the other treatments. Meanwhile, the pollen treatment has two distinctive bands at $62.7(10.9 \%)$ and $87.9 \mathrm{kDa}(4.3 \%)$. In the mean time, the water diluted honey was characterized by 3 bands at $59.3(7.0 \%), 90.0(9.2 \%)$ and $136.3 \mathrm{kDa}$ (7.4\%). This led to speculate that the combined treatment caused a quick appearance of new proteins in 2 days old males.

The 16-days old males fed on the same supplements showed total number of bands being 12, 13, 10, 14 and 10 for the control, diluted honey, pollen, royal jelly and the combined treatment, respectively. Three bands in the control were not detected in all treatments at $28.4(5.1 \%), 69.7$ $(9.1 \%)$ and $140.4 \mathrm{kDa}(6.5 \%)$. The extensive effect shown by the combined treatment at the 2-days old treatment did not continue to the 16-days males. This treatment has given only two distinctive bands at $73.0(7.6 \%)$ and $200 \mathrm{kDa}(7.1 \%)$. While the royal jelly treatment showed six bands at $25.1(6.6 \%)$, 
$52.3(9.8 \%), 62.9(6.1 \%), 89.9(6.3 \%), 116(5.0 \%)$ and $180.2 \mathrm{kDa}(6.5 \%)$. The pollen treatment gave two protein bands at $46.7(10.4 \%)$ and $86.3 \mathrm{kDa}$ $(10.5 \%)$. The water-diluted honey gave three protein bands at $30.9(3.8 \%), 50.3(6.0 \%)$ and $81.9 \mathrm{kDa}$ (13.4\%). The effect of feeding on the above food supplements, for longer periods of time was obvious when compared to the 2-days old males especially at the royal jelly treatment where the number of protein characteristic bands was higher than all of other supplements (Fig. 5). When Males fed on the food supplements, most of the proteins appeared between 20 and $56 \mathrm{kDa}$. Some bands were present all the way up to the $200 \mathrm{kDa}$. At the $22 \mathrm{kDa}$ protein, the concentration of this protein was always higher at the 2-days old males than the 16-days old ones in all treatments. In the same manner, the 38 and $40 \mathrm{kDa}$ proteins showed high concentrations in all treatments including the control which is suspected to be one of the key proteins needed for male development. This specific protein was also found in higher concentrations in the 2-days old males than the 16-days old ones except in diluted honey supplement where it increased after 16-days of feeding. The same could be concluded for the $40 \mathrm{kDa}$ protein where it kept a higher concentration in the 16-days old males for the control $(22.42 \%)$ while the rest of the treatments either were less than the 2-days old males or disappeared totally. The pollen treatment was an exception since the 16-days old males had $17 \%$ of that protein and it was lacking in the 2-days old. At the $42 \mathrm{kDa}$, water diluted honey, pollen and the combined treatment showed an increase in the amount of this protein after 16days. Meanwhile, at the $46 \mathrm{kDa}$, all proteins disappeared after 16-days of feeding except for the pollen where it appeared only after 16-days. The 54 $\mathrm{kDa}$ protein band was at its highest $(14.51 \%)$ at the combined treatment after 16-days compared to the other 16-days treatments. While the $56 \mathrm{kDa}$ was at its highest with pollen after 16-days as well. The 70 $\mathrm{kDa}$ protein appeared only after 16-days in the control $(9.11 \%)$ and the combined treatment (7.63\%). The $96 \mathrm{kDa}$ also appeared after 16-days in the royal jelly $(4.89 \%)$ and the combined treatment (5.48\%). Also, the $102 \mathrm{kDa}$ protein was found only after 16-days of feeding in all treatments except the control $(\mathrm{H})$ and the royal jelly. The same trend was found in the 122 and $174 \mathrm{kDa}$ but only at the treatment of diluted honey \& the pollen. The 180 $\mathrm{kDa}$ at the royal jelly $(6.54 \%)$ and the $200 \mathrm{kDa}$ at the combined treatment were very distinctive (7.1\%). On the other hand, the $98 \mathrm{kDa}$ protein band was only detected after 2-days in all food supplements in addition to the control. While the $112 \mathrm{kDa}$ appeared after 2-days only in pollen (5.99\%) and royal jelly $(6.53 \%)$.

A parallel study on the effects of the above mentioned food supplements, was conducted on the females of $A$. galleriae. At the 2-days old females, total numbers of protein bands were 14, 16, 16, 13 and 15 for the control, diluted honey, pollen, royal jelly and the combined treatment, respectively (Fig. 6). The three bands which appeared in the control was not repeated in any of the treatments. The protein bands were at $16.2(9.3 \%), 97.0(5.5 \%)$ and $104.1 \mathrm{kDa}(5.6 \%)$. The water-diluted honey has also shown three bands at $44.3(4.4 \%), 93.1(3.4 \%)$ and $108.7 \mathrm{kDa}(5.4 \%)$. Meanwhile, the pollen supplement was characterized by only two protein bands at $24.0(11.8 \%)$ and $58.2 \mathrm{kDa}(2.6 \%)$. The royal jelly treatment showed only one protein band at $90.5 \mathrm{kDa}(5.3 \%)$. However, no characteristic protein bands were detected for the combined treatment.

As for the 16-days old females fed on the same set of food supplements, the total number of bands were 15, 11, 15, 13 and 12 for the control (honey fed only), diluted honey, pollen, royal jelly and the combined treatment, respectively. The control was characterized by the appearance of five bands not found in any of the other treatments. These bands were at $10.53(6.6 \%), 16.2(8.7 \%), 80.2(4.8 \%)$, $99.7(4.2 \%)$ and $136.7 \mathrm{kDa}(4.4 \%)$. While the waterdiluted honey had four distinctive bands at 40.1 $(8.3 \%), 45.0(3.8 \%), 75.8(4.7 \%)$ and $116.0 \mathrm{kDa}$ $(11.6 \%)$. Pollen supplementation had four distinctive bands at $12.7(6.8 \%), 44.3(4.1 \%), 70.6$ (4.1\%) and $104.1 \mathrm{kDa}(5.2 \%)$. No distinctive protein banding appeared at the royal jelly treatment. Meanwhile, the combined treatment showed two bands at $30.2(6.4 \%)$ and $85.6 \mathrm{kDa}(7.4 \%)$ (Fig. 6). Protein banding started to appear from the $10 \mathrm{kDa}$ onward with most of the protein banding occurred between 18 till $58 \mathrm{kDa}$. Protein banding continued sporadically from $60 \mathrm{kDa}$ till $182 \mathrm{kDa}$ only. The band matrix showed that proteins at 20, 22, 24, 26, 38 , and $56 \mathrm{kDa}$ were found in all treatments as well as the control. Some of these bands may disappear in the 2 or 16-days old females but not in both ages. After 2-days, the $60 \mathrm{kDa}$ protein appeared only in the royal jelly $(3.7 \%)$ and the combined treatment $(8.4 \%)$. The $66 \mathrm{kDa}$ appeared also after 2-days in the control $(5.2 \%)$ and the diluted honey $(4.5 \%)$ only. In the meantime, the $86 \mathrm{kDa}$ protein appeared after 2-days in pollen and the combined treatment but continued in later to the 16 -days old females $(7.4 \%)$. While the $100 \mathrm{kDa}$ appeared after 2-days in pollen and the combined treatment except for the control where it appeared after 16-days of feeding. The $136 \mathrm{kDa}$ protein appeared after 2-days in pollen $(5.4 \%)$, royal jelly $(6.7 \%)$ and the combined treatment $(7.2 \%)$, while it was found after 16-days in the control $(4.4 \%)$. The highest molecular weight was at $182 \mathrm{kDa}$, appeared only in control $(3.9 \%)$ and in the diluted honey $(3.6 \%)$ after $2-$ days. 
Meanwhile, the $94 \mathrm{kDa}$ appeared after 16-days in the pollen $(4.5 \%)$ and the royal jelly $(7.7 \%)$ but appeared after 2-days in diluted honey (3.4\%). The same trend was noticed for the $108 \mathrm{kDa}$ protein where it appeared after 16-days in royal jelly (9.6\%) and the combined treatment $(13.2 \%)$ but in the diluted honey (5.4\%) after two days of feeding. The effect of food supplementation on the females was affected by time. At the 2-days old females, the supplementation have shown higher molecular weight proteins reaching up to $182.0 \mathrm{kDa}$ for the control and diluted honey. While, the 16-days old ones have only reached $136.7 \mathrm{kDa}$ at the control.

The larvae of $A$. galleriae were dissected out of their hosts. These larvae were from eggs laid by females fed on the above mentioned food supplements. Only the late third instar larvae were analyzed for their protein patterns. The total number of protein bands for these larvae were 12, 11, 10, 10 and 10 bands for the control, diluted honey, pollen, royal jelly and the combined treatment. The protein bands characterizing the control and which were not found in the other treatments were three at 83.4 $(6.7 \%), 103.3(5.2 \%)$ and $172.6 \mathrm{kDa}(5.8 \%)$. The water-diluted honey showed only one band at 52.2 $\mathrm{kDa}(8.2 \%)$. Meanwhile, the pollen supplement gave three distinctive bands at 36.8 (10.4\%), 50.5 $(2.9 \%)$ and $70.1 \mathrm{kDa}(12.0 \%)$. Characteristic bands of the royal jelly treatment were two at $73.7(2.3 \%)$ and $187.7 \mathrm{kDa}(6.8 \%)$. The combined. Treatment was characterized by four protein bands at 23.1 (7.2\%), $56.6(11.9 \%), 78.6(7.2 \%)$ and $200 \mathrm{kDa}$ (7.8\%) (Fig.7).

The protein distribution of the last larval instar was also studied to show the effects of food supplementation given to the adults. Hosts were dissected and the late $3^{\text {rd }}$ larval instars of the endoparasitoid A. galleriae were collected for this experiment. The $22 \mathrm{kDa}$ protein was specific for the larval stage eventually; it disappeared at the combined treatment. The same was noticed for the $36 \mathrm{kDa}$ protein where it appeared under the effect of the pollen feeding $(10.4 \%)$. The protein at $40 \mathrm{kDa}$, $44 \mathrm{kDa}, 50 \mathrm{kDa}$ and $52 \mathrm{kDa}$ were also specific for the larval stage, although they differ between the treatments.

The pupal stage of $A$. galleriae of the corresponding females fed on the above mentioned food supplements was collected from cocoons that did not reach to the pharate adults for the protein profile determination. Total numbers of protein bands were $6,5,5,5$ and 4 bands for the control $(\mathrm{H})$, water diluted honey, pollen, royal jelly and the combined treatment, respectively. Only one band characterizing the control was found at $37.9 \mathrm{kDa}$ $(9.6 \%)$. The same was noticed for the royal jelly treatment at $47.3 \mathrm{kDa}(12.7 \%)$. No distinctive banding was detected for diluted honey, pollen and the combined treatment. All pupal protein bands were between 24 to $54 \mathrm{kDa}$ with no high molecular weight proteins. Fewer number of protein band was also noticed (Fig. 8). Unlike the larval stage only one protein was specific for the pupal stage at 48 $\mathrm{kDa}(12.7 \%)$ with the royal jelly treatment. The 24 $\mathrm{kDa}$ protein also seemed to be specific for the pupal stage where it appeared in all treatments along with the control, eventually, it appeared at the larval stage at the combined treatment. This protein is also found at high concentration especially with the combined treatment being $40.2 \%$.

Similar to the larval stage, the $54 \mathrm{kDa}$ protein was important where it appeared in all treatments including the control. The highest concentration of this particular protein was $28.0 \%$ as an effect of the combined treatment supplement, while, the lowest was $15.1 \%$ under the royal jelly supplement. No protein banding was detected higher than the 54 $\mathrm{kDa}$. Except for the $54 \mathrm{kDa}$ protein, all other proteins appeared commonly with both larvae and pupae. The $54 \mathrm{kDa}$ protein seems to be an important protein which appears in all treatments including the control with its highest concentration at the royal jelly supplement being $31.5 \%$. All proteins above the $54 \mathrm{kDa}$ were found in the larval stage only differing between treatments. High molecular weight proteins appeared with the royal jelly at 188 $\mathrm{kDa}(6.8 \%)$ and with the combined treatment at 200 $\mathrm{kDa}(7.8 \%)$.

In conclusion, protein accumulation in the female parasitic wasps started much earlier than the males, the third A. galleriae larval instar responded to almost all treatments while the pupal stage protein build-up was higher in the HWPRJ treatment, In general, the female protein contents were significantly higher in HWP, HWRJ and HWPRJ than other treatments and the males as well. The protein bands distributions and densities were characteristically variable over time, food supplement and insect stages. It remains a challenge to identify proteins and to relate them to their functions. The present study shows that non-host food supplements can have a profound effect on the protein profile of parasitoid system. To our knowledge, this study is considered one of the very few that deals with the protein profiling of the parasitic wasp, Apanteles galleriae (Hymenoptera: Braconidae).

\section{ACKNOWLEDGEMENT}

The authors would like to express their cordial appreciation to Dr. E.I. El-Agamy (Department of Dairy Sciences) and Dr. A. Farahat (Department of Pesticide Chemistry) for their valuable assistance during the course of the study. 


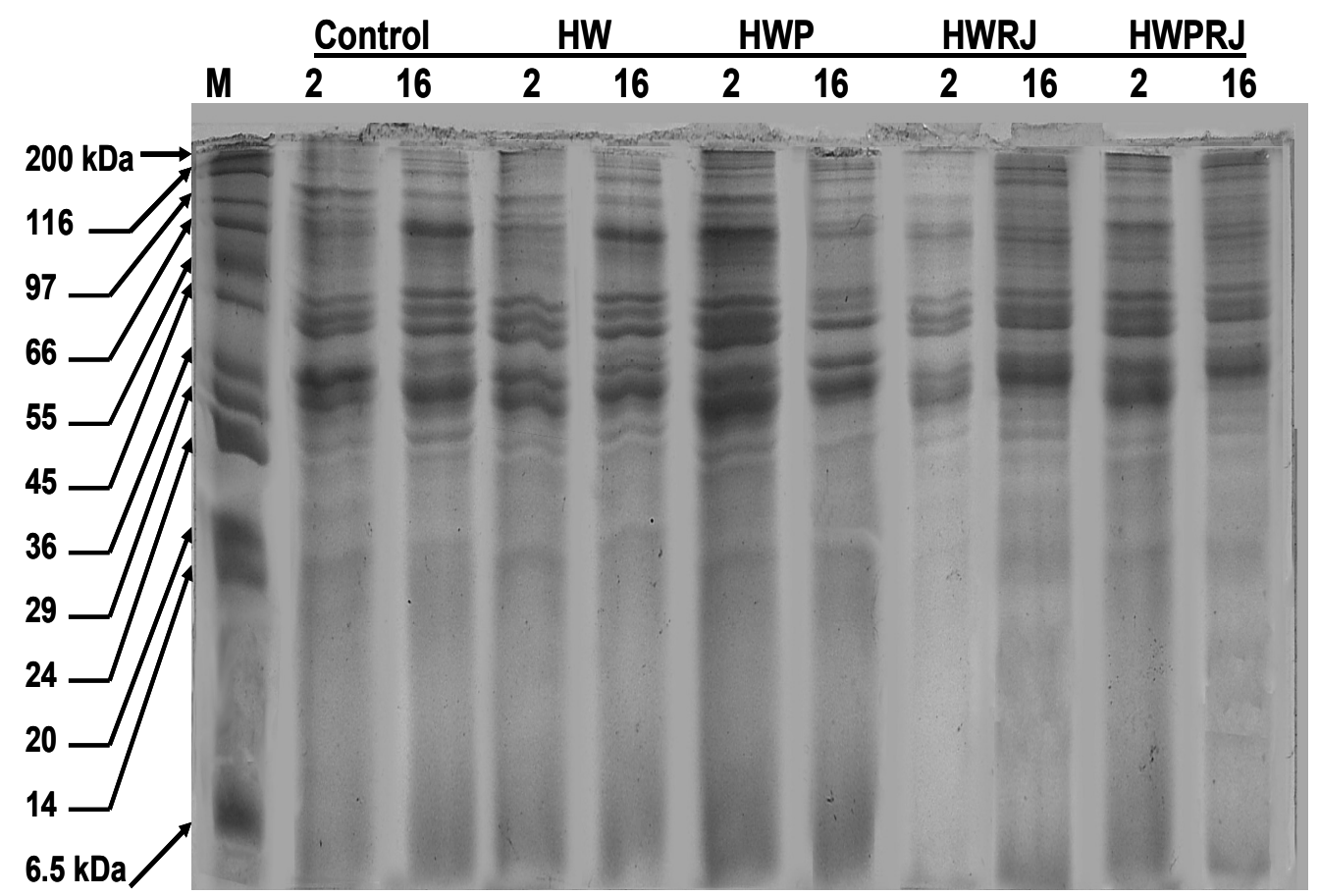

Figure 5: The SDS-PAGE of adult males, $A$. galleriae showing the protein profile when fed on control honey (H), diluted honey (HW), pollen (HWP), royal jelly (HWRJ) and both pollen and royal jelly (HWPRJ) for 2 and 16 days. The standard protein marker (M) is shown at the first lane.

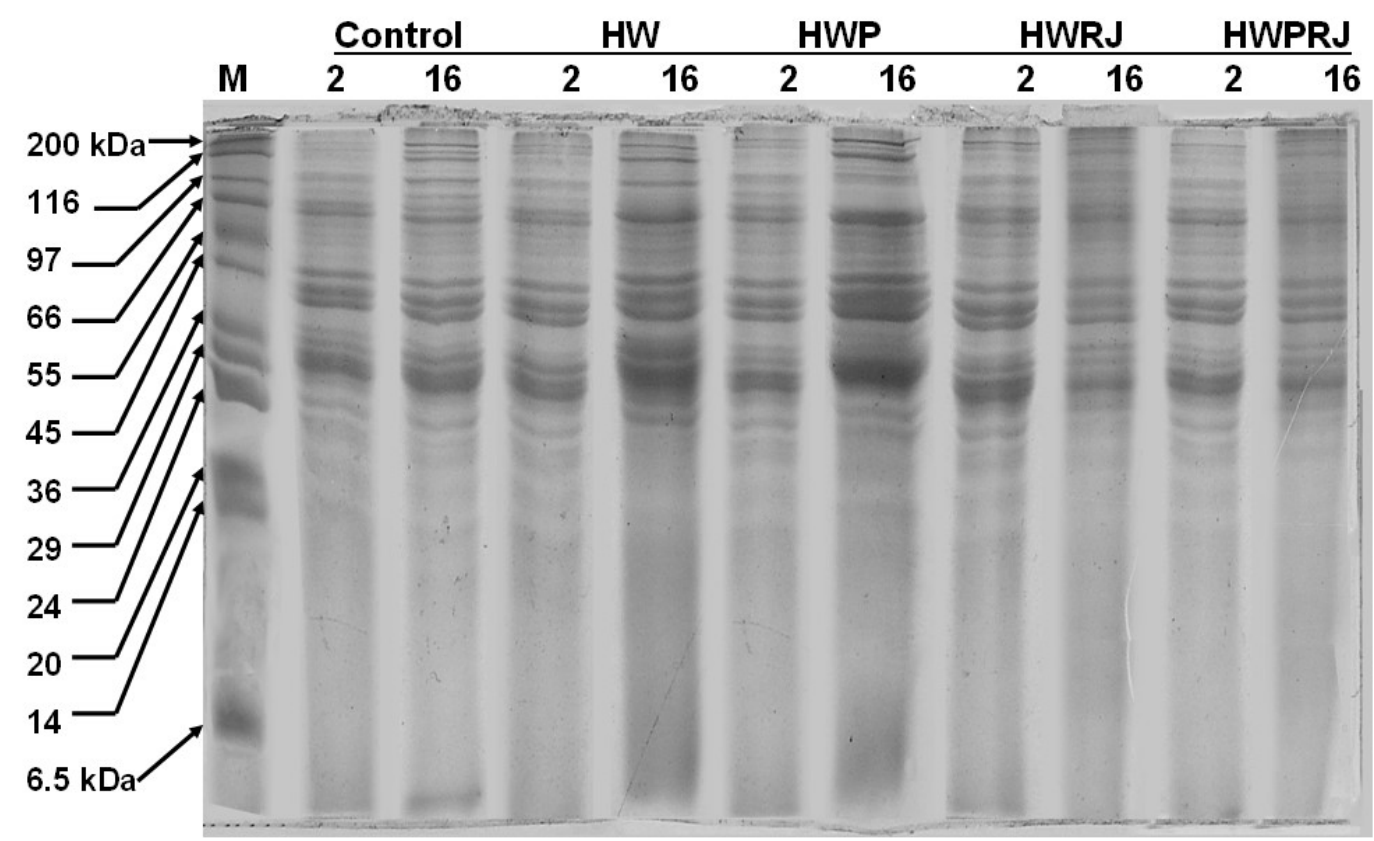

Figure 6: The SDS-PAGE of adult females, A. galleriae showing the protein profile when fed on control honey (H), diluted honey (HW), pollen (HWP), royal jelly (HWRJ) and both pollen and royal jelly (HWPRJ) for 2 and 16 days. The standard protein marker (M) is shown at the first lane. 


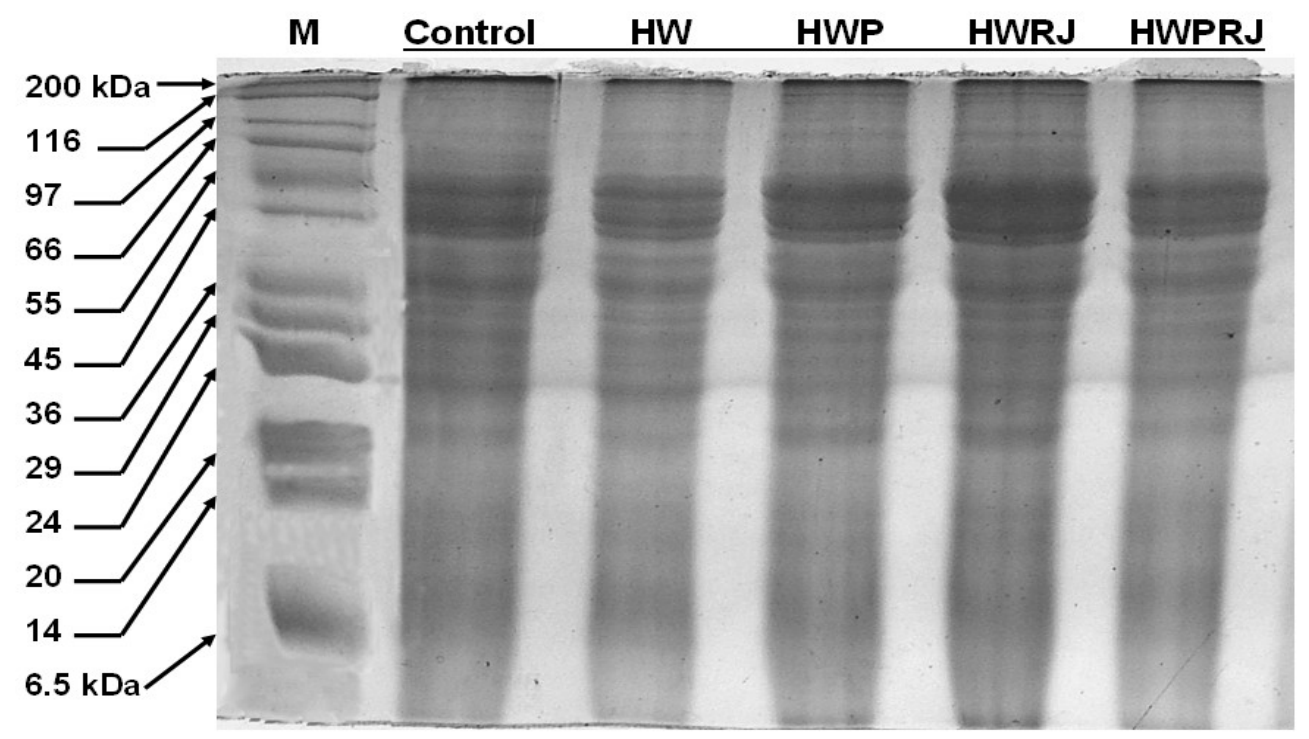

Figure 7: The SDS-PAGE of the larval stage of, $A$. galleriae showing their protein profile when fed (as adults) on control honey $(\mathrm{H})$, diluted honey $(\mathrm{HW})$, pollen (HWP), royal jelly (HWRJ) and both pollen and royal jelly (HWPRJ). The standard protein marker (M) is shown at the first lane.

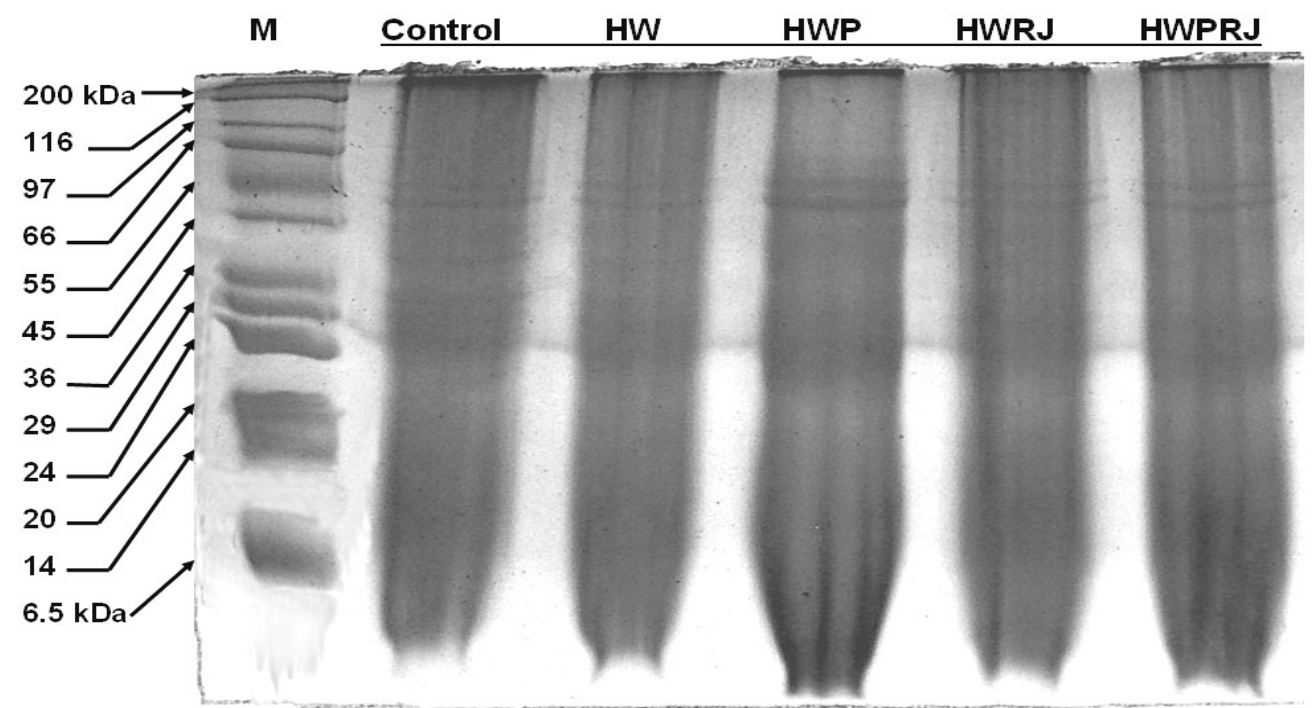

Figure 8: The SDS-PAGE of the pupal stage of, $A$. galleriae showing their protein profile when fed (as adults) on control honey $(\mathrm{H})$, diluted honey $(\mathrm{HW})$, pollen (HWP), royal jelly (HWRJ) and both pollen and royal jelly (HWPRJ). The standard protein marker (M) is shown at the first lane.

Table 3: Distinctive protein bands appeared in the controls of the males (2 and 16 days old), females (2 and 16 days old), larvae and pupae.

\begin{tabular}{|c|c|c|c|c|c|c|}
\hline \multirow[b]{3}{*}{ Number } & \multicolumn{6}{|c|}{ Molecular Weight (kDa) } \\
\hline & \multicolumn{2}{|c|}{ Males } & \multicolumn{2}{|c|}{ Females } & \multirow[b]{2}{*}{ Larvae } & \multirow[b]{2}{*}{ Pupat } \\
\hline & $2 \mathrm{D}$ & $16 \mathrm{D}$ & $2 \mathrm{D}$ & $16 \mathrm{D}$ & & \\
\hline 1 & 50.5 & 36.5 & 66 & 10.53 & 32.8 & -- \\
\hline 2 & 67.5 & 43.1 & 182.1 & 58.2 & 60.4 & -- \\
\hline 3 & 84.9 & 69.7 & -- & 80.2 & 83.4 & -- \\
\hline 4 & 119.8 & 100.7 & -- & 136.7 & 172.6 & -- \\
\hline 5 & -- & 140.4 & -- & -- & -- & -- \\
\hline
\end{tabular}


Table 4: Protein band distributions (\%) of A. galleriae males fed on control honey (H), diluted honey (HW), pollen (HWP), royal jelly (HWRJ) and both pollen and royal jelly (HWPRJ) for 2 and 16 days.

\begin{tabular}{|c|c|c|c|c|c|c|c|c|c|c|}
\hline \multirow[t]{2}{*}{ MW (kDa) } & \multicolumn{2}{|c|}{ Control } & \multicolumn{2}{|c|}{ HW } & \multicolumn{2}{|c|}{ HWP } & \multicolumn{2}{|c|}{ HWRJ } & \multicolumn{2}{|c|}{ HWPRJ } \\
\hline & $2 \mathrm{D}$ & $16 \mathrm{D}$ & $2 \mathrm{D}$ & $16 \mathrm{D}$ & $2 \mathrm{D}$ & $16 \mathrm{D}$ & $2 \mathrm{D}$ & $16 \mathrm{D}$ & $2 \mathrm{D}$ & $16 \mathrm{D}$ \\
\hline 20 & 9.34 & -- & -- & -- & -- & -- & -- & -- & -- & -- \\
\hline 22 & 7.17 & 7.96 & 9.04 & -- & 7.18 & -- & 9.13 & 7.96 & 9.49 & 8.39 \\
\hline 24 & -- & -- & -- & 5.85 & -- & 11.14 & -- & -- & -- & -- \\
\hline 26 & 6.84 & -- & -- & -- & 4.56 & -- & -- & 6.63 & -- & -- \\
\hline 28 & -- & 5.1 & -- & -- & -- & -- & -- & -- & 5.65 & -- \\
\hline 30 & -- & -- & -- & 3.78 & 4.68 & -- & 11.3 & -- & -- & -- \\
\hline 32 & 7.28 & 6.52 & 8.74 & -- & -- & -- & -- & 4.74 & 6.35 & 6.4 \\
\hline 36 & -- & 7.75 & -- & 5.59 & -- & 7.79 & -- & 5.65 & -- & -- \\
\hline 38 & 11.98 & -- & 10.96 & 13.14 & 25.43 & -- & 15.74 & 9.36 & 14.5 & 7.29 \\
\hline 40 & 9.0 & 22.42 & 11.32 & -- & -- & 17 & 11.94 & 7.64 & 10.81 & -- \\
\hline 42 & 6.88 & -- & 7.78 & 11.11 & 8.21 & 12.24 & -- & -- & -- & 12.3 \\
\hline 44 & -- & 8.91 & -- & 9.96 & 5.73 & -- & 7.78 & 7.97 & 10.72 & -- \\
\hline 46 & 5.6 & -- & 10.96 & -- & -- & 10.37 & 12.35 & -- & -- & -- \\
\hline 48 & -- & 7.12 & -- & -- & -- & -- & -- & -- & -- & 3.81 \\
\hline 50 & 5.51 & -- & -- & 6.02 & 7.5 & -- & -- & -- & 7.6 & -- \\
\hline 52 & -- & -- & -- & -- & -- & -- & -- & 9.75 & -- & -- \\
\hline 54 & -- & 5.5 & 8.41 & 7.58 & 10.73 & -- & 8.77 & 5.75 & 7.51 & 14.51 \\
\hline 56 & 7.08 & 7.99 & 4.09 & 8.37 & -- & 13.54 & -- & 5.73 & -- & 5.82 \\
\hline 58 & -- & -- & -- & -- & -- & -- & -- & -- & 8.39 & -- \\
\hline 60 & -- & -- & 6.95 & -- & -- & -- & -- & -- & -- & -- \\
\hline 62 & -- & -- & -- & -- & 10.89 & -- & -- & 6.11 & -- & -- \\
\hline 68 & 8.63 & -- & -- & -- & -- & -- & -- & -- & -- & -- \\
\hline 70 & -- & 9.11 & -- & -- & -- & -- & -- & -- & -- & 7.63 \\
\hline 76 & -- & -- & -- & -- & -- & -- & 10.08 & -- & -- & -- \\
\hline 82 & -- & -- & -- & 13.41 & -- & -- & -- & -- & -- & -- \\
\hline 84 & 3.85 & -- & -- & -- & -- & -- & -- & -- & -- & -- \\
\hline 86 & -- & -- & -- & -- & -- & 10.51 & -- & -- & 6.75 & -- \\
\hline 88 & -- & -- & -- & -- & 4.28 & -- & -- & -- & -- & -- \\
\hline 90 & -- & -- & 9.21 & -- & -- & -- & -- & 6.27 & -- & -- \\
\hline 96 & -- & -- & -- & -- & -- & -- & -- & 4.89 & -- & 5.48 \\
\hline 98 & 5.41 & -- & 5.12 & -- & 4.8 & -- & 6.38 & -- & 3.12 & -- \\
\hline 100 & -- & 5.12 & -- & -- & -- & -- & -- & -- & -- & -- \\
\hline 102 & -- & -- & -- & 6.32 & -- & 5.22 & -- & -- & -- & 5.58 \\
\hline 112 & -- & -- & -- & -- & 5.99 & -- & 6.53 & -- & -- & -- \\
\hline 116 & -- & -- & -- & -- & -- & -- & -- & 5.0 & -- & -- \\
\hline 120 & 5.45 & -- & -- & -- & -- & -- & -- & -- & -- & -- \\
\hline 122 & -- & -- & -- & 4.88 & -- & 6.1 & -- & -- & -- & -- \\
\hline 136 & -- & -- & 7.43 & -- & -- & -- & -- & -- & -- & -- \\
\hline 140 & -- & 6.51 & -- & -- & -- & -- & -- & -- & -- & -- \\
\hline 172 & -- & -- & -- & -- & -- & -- & -- & -- & 9.0 & -- \\
\hline 174 & -- & -- & -- & 3.98 & -- & 6.09 & -- & -- & -- & -- \\
\hline 180 & -- & -- & -- & -- & -- & -- & -- & 6.54 & -- & -- \\
\hline 200 & -- & -- & -- & -- & -- & -- & -- & -- & -- & 7.1 \\
\hline
\end{tabular}


Table 5: Protein band distributions (\%) of A. galleriae females fed on control honey (H), diluted honey (HW), pollen (HWP), royal jelly (HWRJ) and both pollen and royal jelly (HWPRJ) for 2 and 16 days

\begin{tabular}{|c|c|c|c|c|c|c|c|c|c|c|}
\hline \multirow{2}{*}{$\begin{array}{l}\text { MW } \\
(\mathrm{kDa})\end{array}$} & \multicolumn{2}{|c|}{ Control } & \multicolumn{2}{|c|}{ HW } & \multicolumn{2}{|c|}{ HWP } & \multicolumn{2}{|c|}{ HWRJ } & \multicolumn{2}{|c|}{ HWPRJ } \\
\hline & $2 \mathrm{D}$ & $16 \mathrm{D}$ & $2 \mathrm{D}$ & $16 \mathrm{D}$ & $2 \mathrm{D}$ & $16 \mathrm{D}$ & $2 \mathrm{D}$ & $16 \mathrm{D}$ & $2 \mathrm{D}$ & $16 \mathrm{D}$ \\
\hline 10 & -- & 6.64 & 8.4 & -- & 8.38 & -- & -- & -- & -- & -- \\
\hline 12 & -- & -- & -- & -- & -- & 6.79 & -- & -- & -- & -- \\
\hline 14 & -- & -- & 5.97 & -- & 4.92 & -- & 6.8 & -- & 6.27 & -- \\
\hline 16 & 9.32 & 8.67 & -- & -- & -- & -- & -- & -- & -- & -- \\
\hline 18 & -- & -- & 5.87 & -- & 7.63 & 5.39 & 7.06 & 5.97 & 7.06 & -- \\
\hline 20 & 8.35 & 5.28 & 6.22 & 8.78 & 5.03 & 5.83 & 6.06 & 6.72 & 5.68 & 7.5 \\
\hline 22 & 5.51 & 4.82 & 8.33 & 3.57 & -- & 6.95 & 12.2 & 9.99 & 14.54 & 7.05 \\
\hline 24 & -- & 13.41 & -- & 14.67 & 11.8 & -- & -- & 9.14 & -- & 14.69 \\
\hline 26 & 9.86 & 6.64 & 8.34 & -- & 1.73 & 17.43 & 12.03 & 6.08 & 1.7 & 2.52 \\
\hline 28 & 9.05 & -- & 4.07 & 10.69 & 5.26 & -- & -- & 6.21 & 5.87 & -- \\
\hline 30 & -- & -- & -- & -- & -- & -- & -- & -- & -- & 6.39 \\
\hline 32 & 5.9 & 5.45 & -- & -- & -- & 5.61 & -- & -- & -- & -- \\
\hline 34 & -- & -- & 6.1 & 9.66 & 8.05 & -- & 5.64 & 9.29 & 6.05 & 8.95 \\
\hline 38 & 6.26 & 8.4 & 6.77 & 8.21 & 7.45 & 6.77 & 7.38 & 5.6 & 8.09 & 8.68 \\
\hline 40 & -- & -- & -- & 8.25 & 5.35 & -- & 6.66 & -- & -- & -- \\
\hline 42 & -- & 5.94 & 6.45 & -- & -- & 7.25 & -- & 8.35 & 6.12 & 8.22 \\
\hline 44 & -- & -- & 4.41 & -- & -- & 4.05 & -- & -- & -- & -- \\
\hline 46 & 11.96 & -- & -- & 3.83 & -- & -- & 5.47 & -- & -- & -- \\
\hline 48 & -- & 6.69 & -- & 6.11 & 4.36 & -- & -- & -- & 5.32 & -- \\
\hline 50 & -- & -- & 5.59 & -- & -- & 6.68 & 4.98 & -- & -- & -- \\
\hline 52 & -- & -- & -- & -- & -- & -- & -- & 2.76 & -- & 3.65 \\
\hline 54 & 5.48 & -- & -- & -- & -- & -- & -- & -- & 8.84 & -- \\
\hline 56 & 8.18 & 10.17 & 6.55 & 9.97 & 11.23 & 9.8 & 10.04 & -- & -- & 11.79 \\
\hline 58 & -- & 4.48 & -- & -- & 2.6 & 3.7 & -- & 12.6 & -- & -- \\
\hline 60 & -- & -- & -- & -- & -- & -- & 3.69 & -- & 8.41 & -- \\
\hline 66 & 5.19 & -- & 4.48 & -- & -- & -- & -- & -- & -- & -- \\
\hline 70 & -- & -- & -- & -- & -- & 4.07 & -- & -- & -- & -- \\
\hline 76 & -- & -- & -- & 4.68 & -- & -- & -- & -- & -- & -- \\
\hline 80 & -- & 4.83 & -- & -- & -- & -- & -- & -- & -- & -- \\
\hline 86 & -- & -- & -- & -- & 5.67 & -- & -- & -- & 4.67 & 7.4 \\
\hline 90 & -- & -- & -- & -- & -- & -- & 5.32 & -- & -- & -- \\
\hline 94 & -- & -- & 3.43 & -- & -- & 4.5 & -- & 7.65 & -- & -- \\
\hline 98 & 5.52 & -- & -- & -- & -- & -- & -- & -- & -- & -- \\
\hline 100 & -- & 4.18 & -- & -- & 5.08 & -- & -- & -- & 4.16 & -- \\
\hline 104 & 5.56 & -- & -- & -- & -- & 5.19 & -- & -- & -- & -- \\
\hline 108 & -- & -- & 5.39 & -- & -- & -- & -- & 9.62 & -- & 13.15 \\
\hline 116 & -- & -- & -- & 11.58 & -- & -- & -- & -- & -- & -- \\
\hline 136 & -- & 4.39 & -- & -- & 5.44 & -- & 6.67 & -- & 7.22 & -- \\
\hline 182 & 3.85 & -- & 3.61 & -- & -- & -- & -- & -- & -- & -- \\
\hline
\end{tabular}


Table 6: Protein band distributions (\%) of A. galleriae larvae (L) and pupae (P) fed on control honey, diluted honey (HW), pollen (HWP), royal jelly (HWRJ) and both pollen and royal jelly (HWPRJ)

\begin{tabular}{|c|c|c|c|c|c|c|c|c|c|c|}
\hline \multirow[t]{2}{*}{ MW (kDa) } & \multicolumn{2}{|c|}{ Control } & \multicolumn{2}{|c|}{ HW } & \multicolumn{2}{|c|}{ HWP } & \multicolumn{2}{|c|}{ HWRJ } & \multicolumn{2}{|c|}{ HWPRJ } \\
\hline & $\mathbf{L}$ & $\mathbf{P}$ & $\mathbf{L}$ & $\mathbf{P}$ & $\mathbf{L}$ & $\mathbf{P}$ & $\mathbf{L}$ & $\mathbf{P}$ & $\mathbf{L}$ & $\mathbf{P}$ \\
\hline 22 & 7.21 & -- & 4.65 & -- & 9.89 & -- & 7.12 & -- & -- & -- \\
\hline 24 & -- & 22.69 & -- & 16.42 & -- & 20.33 & -- & 29.26 & 7.18 & 40.24 \\
\hline 26 & 8.74 & -- & 11.66 & -- & 9.41 & 19.89 & 8.74 & -- & 10.32 & 13.08 \\
\hline 28 & 7.21 & 15.6 & 8.14 & 22.75 & 7.75 & -- & -- & 22.31 & -- & -- \\
\hline 30 & 6.86 & -- & 5.77 & -- & -- & 19.04 & 8.95 & 20.64 & -- & -- \\
\hline 32 & 6.62 & 17.24 & 7 & 21.96 & 12.12 & -- & 6.74 & -- & 8.38 & -- \\
\hline 36 & -- & -- & -- & -- & 10.42 & -- & -- & -- & -- & -- \\
\hline 38 & -- & 9.56 & 12.3 & -- & -- & -- & 10.29 & -- & -- & -- \\
\hline 40 & 9.29 & -- & -- & -- & -- & -- & -- & -- & 12.94 & -- \\
\hline 44 & -- & -- & 8.61 & -- & 9.98 & -- & -- & -- & -- & -- \\
\hline 46 & 6.69 & 18.46 & -- & 15.97 & -- & 22.7 & 9.92 & -- & 8.39 & 18.67 \\
\hline 48 & -- & -- & -- & -- & -- & -- & -- & 12.7 & -- & -- \\
\hline 50 & -- & -- & -- & -- & 2.88 & -- & -- & -- & -- & -- \\
\hline 52 & -- & -- & 8.18 & -- & -- & -- & -- & -- & -- & -- \\
\hline 54 & 20.06 & 16.46 & 18.85 & 22.9 & 16.07 & 18.04 & 31.45 & 15.09 & 16.97 & 28.01 \\
\hline 56 & -- & -- & -- & -- & -- & -- & -- & -- & 11.85 & -- \\
\hline 60 & 7.59 & -- & 7.99 & -- & -- & -- & -- & -- & -- & -- \\
\hline 70 & -- & -- & -- & -- & 12.03 & -- & -- & -- & -- & -- \\
\hline 74 & -- & -- & -- & -- & -- & -- & 2.26 & -- & -- & -- \\
\hline 78 & -- & -- & -- & -- & -- & -- & -- & -- & 7.2 & -- \\
\hline 84 & 6.69 & -- & -- & -- & -- & -- & -- & -- & -- & -- \\
\hline 100 & -- & -- & 6.84 & -- & -- & -- & -- & -- & 9.01 & -- \\
\hline 102 & -- & -- & -- & -- & 9.45 & -- & 7.38 & -- & -- & -- \\
\hline 104 & 5.2 & -- & -- & -- & -- & -- & -- & -- & -- & -- \\
\hline 172 & 5.83 & -- & -- & -- & -- & -- & -- & -- & -- & -- \\
\hline 188 & -- & -- & -- & -- & -- & -- & 6.75 & -- & -- & -- \\
\hline 200 & -- & -- & -- & -- & -- & -- & -- & -- & 7.75 & -- \\
\hline
\end{tabular}

Molecular weight (MW, $\mathrm{kDa})$ missing values showed no protein bands.

\section{REFERENCES}

Abo Abdalla, L.M.Z. (2006). Effect of food supplements on the bionomics and reproductive potential of the wax moth parasitoid, Apanteles galleriae Wilk.(Hymenoptera: Braconidae).Egyptian Journal of Biological Pest Control 16 (2): 8792.

Al-Arnaooty, S.A.G. (1985). Studies on the natural enemies of wax moths with special reference to the biology of the braconid parasitoid Apanteles galleriae Wilk. M.Sc. Thesis, Faculty of Agriculture, Cairo University. 146 pp.

Andow, D. A.; D. W. Ragsdale and R. F. Nyvall (1997). Ecological Interactions and Biological Control. Colorado: Westview Press.

Awadallah, K.T.; M.F.S. Tawfik and M.M.H. Abdellah (1985). Biocycle of Bracon hebetor Say. (Hymenoptera: Braconidae) on the greater wax moth, Galleria mellonella L. (Lepidoptera: Pyralidae) Annals of Agriculture Science Moshtohor 23 (1): 343350.
Benton, A. H. and A. J. Crump (1981). Observations on the spring and summer behavior of the 12spotted ladybird beetle, Coleomegilla maculate (DeGeer) (Coleoptera: Ciccinellidae). Journal of the New York Entomological Society 89: 102-108.

Boldt, P.E. and N. Marston (1974). Eggs of the greater wax moth as a host for Trichgramma . Environmental Entomology (3): 545-548.

Chen, I. C. and S.Y. Chen (1995). Changes in protein components and storage stability of Royal jelly under varios conditions. Food Chemistry 54: 195-200.

El-Hemaesy, A.H. (1983). Studies on the braconid parasitoid Apanteles galleria Wilk., a new record parasitizing wax worm in Egypt. Proc.5 Arab Pesticide Conference, Tanta University. 1: 122-136.

El-Kifl, T. (1980). Utilization of the nematode Neoapleciona carpocapsae in the biological control of the cotton leaf worm Spodoptera littoralis MSc. Thesis Faculty of. Agriculture, Cairo University. 125pp.

Gomez, K.A. and A. A.Gomez (1984). Statistical procedures for agriculture research. $2^{\text {nd }} \mathrm{ed}$, John Wiely and Sons, New York, USA. 
Goss, J. A. (1968). Development, physiology, and biochemistry of corn and wheat pollen. The Botanical Review 34: 333-358.

Hagen, K. S. (1962). Biology and ecology of predaceous Coccinellidae. Annual Review of Entomology 7: 289-326.

Hagen, K. S. (1986). Ecosystem and analysis: Plant cultivars(HPR), entomophagous species and food supplements. In: Boethel, D. J. Eikenbary, R. D. (Eds.), Interactions of Plant Resistance and Parasitoids and Predators of Insects. Ellis Horwood Limited, West Sussex. England, pp. 151-197.

Hemptinne, J. L. and A. Desprets (1986). Pollen as a spring food for Adalia bipunctata. In: Hodek, I. (Ed.), Ecology of Aphidophaga. Academia and Dr. W. Junk, Prague and Dordrecht, pp. 29-35.

Hocking, H. (1966). The influence of food on longevity and oviposition in Rhyssa persuasoria (L) (Hymenoptera: Ichneumonidae). Journal of the Australian

Entomological Society 6: 83-88.

Hodek, I. and A. Honek (1996). Ecology of Coccinellidae. Kluwer Academic Publishers, Dordrecht, The Netherlands.

Hokkanen, H.M.T. and J.M. Lynch (1995). Biological Control: Benefits and Risks. New York: Cambridge Univ. Press.

Howe, S. R.; P. S. Dimick, and A.W. Benton (1985). Composition of freshly harvested and commercial royal jelly. Journal of Apicultural Research 24(1): 52-61.

Ibrahim, S.H. (1980). A preliminary study on a new parasite of the wax moth, Galleria mellonella L. Agricultural Research Review 58 (10): 311-314.

Ibrahim, S.H.; A.A. Ibrahim and Y.H. Fayad (1984). Studies on mass rearing of the wax moth, Galleria mellonella L. and its parasite Apanteles galleriae Wilk. with some biological notes on the parasite. Agricultural Research Review 62(1): 349-353.

Jervis, M.A. and N.A.C. Kidd (1986). Host-feeding strategies in hymenopteran parasitoids. Biological Reviews 61: 395-434.

Kehrli, P. and S. Bacher (2008). Differential effects of flower feeding in an insect host-parasitoid system. Basic and Applied Ecology 9: 709717.

Laemmli, U. K. (1970). Cleavage of structural proteins during the assembly of the head of bacteriophage T4. Nature 227: 680-685.

Lowry, O. H.; N. J. Rosenbroug; A. L. Farr and R. J. Randall (1951). Protein measurement of the Folin Reagent. Journal of Biological Chemistry 193: 265-275.
Lundgren, J.G. and R. N. Wiedennmann (2004). Nutritional suitability of Corn Pollen for the predator Coleomegilla maculate (Cleoptera: Coccinellidae). Journal of Insect Physiology 50: $567-575$.

Nordlund, D. A.; A. C. Cohen and R. A. Smith (2001). Mass-rearing, release techniques and augmentation . In: McEwen, P. New, T. R. Whittington, A. E. (Eds.), Lacewings in the Crop Environment. Cambridge University Press Cambridge, UK, pp.303-315.

Olson, D. M. and D. A. Andow (1998). Larval crowding and adult nutrition effects on longevity and fecundity of female Trichogramma nubilale Ertle \& Davis (Hymenoptera: Trichogrammatidae). Enviromental Entomology 27: 508-514.

Roulston, T. H.; J. H. Cane and S. L. Buchmann (2000). What governs protein content of pollen : Pollinator preferences, pollen-pistil interactions, or phylogeny? Ecological Monographs 70: 617-643.

Salt, G. (1976). The hosts of Nemeritis canescens, a problem in the host specificity of insect parasitoids. Ecological Entomology 1: 63-67.

Schmale, I.; F.L. Wäckers; C. Cardona and S. Dorn (2001). Control potential of three hymenopteran parasitoid species against the bean weevil in stored beans: The effect of adult parasitoid nutrition on longevity and progeny production. Biological Control 21: 134-139.

Schmitzova, J.; J. Klaudiny; S. Albert; J. Hanes; W. Schroder; V. Schrockengost; J. Judova and J. Simuth (1998). A family of major royal jelly proteins of the honeybee Apis mellifera L., CMLS Cellular and Molecular Life Sciences 54: 1020-1030.

Schneider, F. (1969). Bionomics and physiology of aphidophagous Syrphidae. Annual Review of Entomology 14: 103-124.

Shimamori, K. (1987). On the biology of Apanteles galleriae a parasite of the two species of wax moths .Honeybee Science 8: 107-112.

Siekmann, G.; B. Tenhumberg and M. A. Keller (2001). Feeding and survival in parasitic wasps: sugar concentration and timing matter. Oikes 95: 425-430.

Simuth, J. (2001). Some properties of the main protein of honeybee (Apis mellifera) Royal jelly. Apidologie 32: 69-80.

Takasu, K. and W.J. Lewis (1995). Importance of adult food sources to host searching of the larval parasitoid Microplitis croceipes. Biological Control 5: 25-30. 
Tamura, S.; T. Kono; C. Harada; K.Yamaguchi and T. Moriyama (2009). Estimation and characterization of major royal jelly proteins obtained from the honeybee Apis mellifera. Food Chemistry 114: 1491-1497.

Tawfik, M.F.S.; K.T. Awadallah, and M.M.H. Abdellah (1985). Natural enemies of the greater wax moth, Galleria mellonella L.with reference to the bionomics of the braconid Apanteles galleriae Wilk. Annals of Agriculture Science, Moshtohor, 23 (1): 335341.

Tharwat, E.E. A. (1991). Biological control of wax moth. MSc. Thesis Faculty of Agriculutre, Ain Shams University. 125 pp.

Uçkan, F. and A. Gülel (2002). Age-related fecundity and sex ratio variation in Apanteles galleriae (Hymenoptera: Braconidae) and host effect on fecundity and sex ratio of its hyperparasitoid Dibrachys boarmiae (Hymenoptera: Pteromalidae). Journal of Applied Entomolgy 126: 534-537.

Van Driesche, R. G. and T. S. Bellows (1996). Biological Control, New York: Champan \& Hall.

Wäckers, F.L. (1994). The effect of food deprivation on the innate visual and olfactory preferences in the parasitoid Cotesia rubecula. Journal of Insect Physiology 40: 641-649.

Wäckers, F.L. (1998). Food supplements to enhance biological control in storage system: effects of hosts and honey on the longevity of the bruchid parasitoids Anisopteromalus calandrae and Heterospilus prosopidis. Proceedings of Experimental and Applied Entomology 9: 47-52.

Wäckers, F.L. (2001). A comparison of nectar and honeydew sugars with respect to their utilization by the hymenopteran parasitoid, Cotesia glomerata. Journal of Insect Physiology 47: 1077-1084.
Wäckers, F.L. (2002). The effect of food supplements on parasitoid-host dynamics. International Symposium on Biological Control of Arthropods, January 14-18.

Wäckers, F. L.; P. C. J. Van Rijin and J. Bruin (2005). Plant-provided food and herbivorecarnivore interactions. A protective mutualism and its applications. Cambridge: Cambridge University Press.

Wade, M. R. and S. D.Wratten (2007). Excised or intact inflorescences? Methodological effects on parasitoid wasp longevity. Biological Control 40: 347-354.

Watanabe, C. (1987). Occurrence of Apanteles galleriae (Hymenoptera: Braconidae), a parasite of wax moth in Japan. Kontyû 55: 165-168.

Whitfield, J.B.; S.A. Cameron, ; S.R. Ramirez, ; K. Roesch,; S. Messinger, ; O.M.

Taylor, and D. Cole (2001). Review of the Apanteles species (Hymenoptera: Braconidae) attacking Lepidoptera in Bombus (Fervidobombus) (Hymenoptera: Apidae) colonies in the new world, with description of a new species from South Africa. Annals of the Entomological Society of America 94: 851-857.

Wiedenmann, R. N.; J. C. Legaspi, and R. J. O Neil (1996). Impact of prey density and facultative plant feeding on the life history of the predator Podisus maculiventris (Heteroptera: Pentatomidae). In: Alomar, O. Wiedenmann, R> N. (Eds.), Zoophytophagous Heteroptera: Implications for Life History and Integrated Pest Manadement. Thomas Say Publications, Entomological Society of America, Lanham, MD, pp. 94-118.

Williams, J.L. (1976). Status of the greater wax moth, Galleria mellonella L. in the United states bee keeping industry. American Bee Journal 116 (11): 524-526.

Wolcott, G.N. (1942). The requirements of parasites for more than hosts. Science 96: 317-318.

Zhou, Y.F.; Y. X. Lue,; H.S. Chen, and Y.S. Lai, (1989). Occurrence and harmfulness of Galleria mellonella L. (Lepidoptera: Pyralidae). Natural Enemies of Insects 11(2): 87-93. 


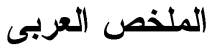

\section{تأثير البدائل الغذانية الطبيعية على المحتوى البروتينى لكل من الاطوار الكاملة واليرقية للطفيل}

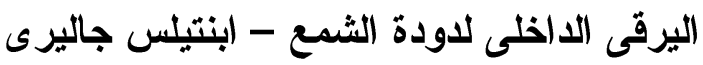

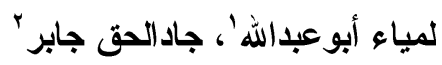

$$
\begin{aligned}
& \text { ' قسم بحوث المكافحة الحيوية - معهد بحوث وقاية النبات - الصباحية - الاسكندرية. } \\
& \text { لقّم الحشرات النطبيقى - كلية الزراعة - جامعة الاسكندرية. }
\end{aligned}
$$

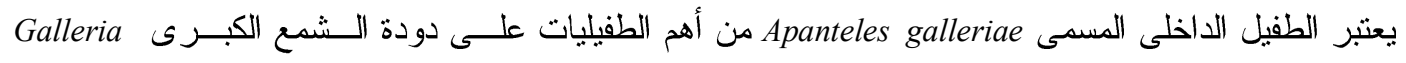
mellonella

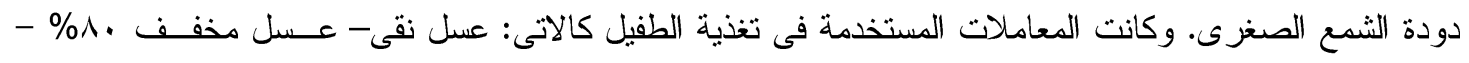

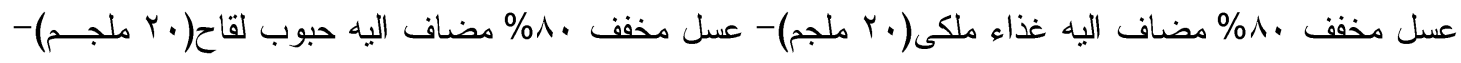

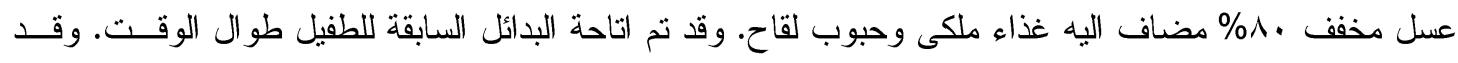

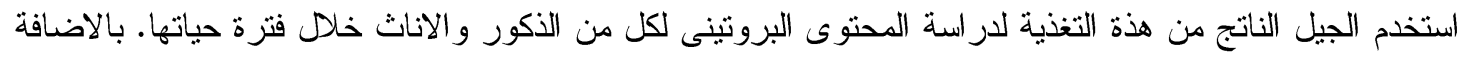

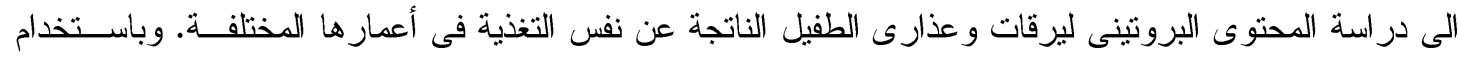

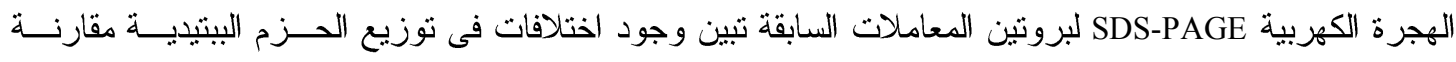

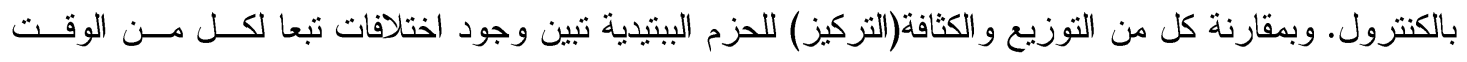
و أطوار الطفيل المختلفة اضافة الى تأثير البدائل الغذائية. 